\title{
Analisa Kelayakan Usaha Produk Susu Kedelai Olahan Home Made di Kota Banda Aceh
}

\author{
Syaifuddin YANA * \\ Fakultas Teknik Industri, Universitas Serambi Mekkah, \\ Jalan Batoh, Lueng Bata, Kota Banda Aceh, Provinsi Aceh, Indonesia \\ syaifuddin.yana@serambimekkah.ac.id \\ BADARUDDIN \\ Fakultas Ekonomi, Universitas Serambi Mekkah, \\ Jalan Batoh, Lueng Bata, Kota Banda Aceh, Provinsi Aceh, Indonesia \\ badaruddin@serambimekkah.ac.id \\ Bisman ALI \\ Fakultas Ekonomi, Universitas Serambi Mekkah, \\ Jalan Batoh, Lueng Bata, Kota Banda Aceh, Provinsi Aceh, Indonesia \\ bismanali@gmail.com
}

Article's history:

Received 15 February 2020; Received in revised form 22 July 2020; Accepted 23 August, 2020;

Published 30 August 2020. All rights reserved to the Lembaga Otonom Lembaga Informasi dan Riset Indonesia (KITA INFO dan RISET).

Suggested citation:

Yana., S, Badaruddin, Ali., B. 2020. Analisa Kelayakan Usaha Produk Susu Kedelai Olahan Home Made di Kota Banda Aceh. JEMSI (Jurnal Ekonomi, Manajemen, dan Akuntansi), Volume 6 (2): 82-89. DOI: https://doi.org/10.35870/jemsi.v6i1.341.

\section{ABSTRAK:}

Kegiatan ini merupakan upaya dalam meningkatkan kesejahteraan dan kemakmuran masyarakat dengan mendirikan investasi/usaha diberbagai bidang industri, salah satunya seperti usaha pembuatan susu kedelai olahan homemade di Kota Banda Aceh. Tujuan dari kegiatan ini yaitu untuk menciptakan lapangan kerja bagi masyarakat luas. Investasi yang baik dapat mendorong pertumbuhan ekonomi daerah dari berbagai perspektif seperti mendorong pendapatan daerah melalui distribusi pajak dan meningkatkan pertumbuhan ekonomi daerah. Analisa kelayakan usaha yang dilakukan untuk produk susu kedelai olahan ini dilakukan melalui beberapa tahap, yakni produk pesaing (product), lokasi/distribusi (place), harga (price), promosi (promotion), analisis peluang pasar, dan analisis aspek finansial. Hasil analisis kelayakan usaha industri susu kedelai menunjukkan bahwa berdasarkan penghitungan BEP pada bulan ke-4 sudah terjual sebanyak 54.645 bungkus dengan BEP Rupiah yaitu sebesar Rp.164.583.334. Dimana total cost sebesar Rp.28.897.000,- dan total revenue sebesar Rp.1.500.000. Setelah dilakukan analisis terhadap hasil perhitungan, maka usaha ini layak untuk di kembangkan di Kota Banda Aceh.

Kata Kunci: Susu Kedelai; Produk; Homemade; Analisa Kelayakan Usaha; Banda Aceh.

JEL Classification: D13; E23; L15.

\section{PENDAHULUAN}

Kedelai merupakan tanaman asli Daratan Cina dan telah dibudidayakan sejak 2500 SM dan mulai dikenal di Indonesia sejak abad ke-16. Pada awalnya, kedelai memiliki beberapa nama botani, yaitu Glycine soja dan Soja max. Namun pada tahun 1948 telah disepakati nama ilmiah untuk kedelai yaitu Glycine max (L.) Merill [1]. Secara umum tanaman kedelai yang dibudidayakan memiliki kedekatan spesies dengan kedelai liar, seperti Glycine cladestina dan Glycine usuriesnsis [2]. Kedelai (Glycine max) merupakan komoditas tanaman pangan terpenting ketiga setelah padi dan jagung. Kedelai mengandung sumber protein nabati yang sangat penting bagi tubuh, serta mudah diperoleh dengan harga yang sangat terjangkau. Kedelai dapat diolah menjadi berbagai olahan pangan seperti tahu, tempe, kecap, susu kedelai, tauco, dan sebagainya [3].

Nilai gizi kedelai Glycine max (L.) Merill dalam 100 gramnya yaitu mengandung 310 kalori, 35\% protein, $18 \%$ lemak, 35 karbohidrat, dan $8 \%$ air. Biji kedelai juga mengandung asam amino yang relatif lebih tinggi bila dibandingkan dengan tanaman serealia lainnya [4]. Selain itu, kedelai menjadi pilihan karena kandungan 
proteinnya yang mencapai $35-38 \%$ atau hampir mendekati kandungan protein susu sapi. Menurut Ref. [5], kandungan lain dalam kedelai seperti saponin, fitosterol, asam lemak omega-3, dan isoflavon mampu mencegah kanker.

Salah satu upaya untuk meningkatkan kesejahteraan dan kemakmuran masyarakat adalah dengan melakukan investasi, seperti mendirikan usaha-usaha diberbagai bidang seperti industri baik skala kecil, menengah, maupun besar. Tujuan investasi tersebut diantaranya dapat menciptakan lapangan kerja bagi masyarakat luas. Investasi yang sehat dapat mendorong pertumbuhan ekonomi daerah dari berbagai perspektif seperti mendorong pendapatan daerah melalui distribusi pajak, aktivitas usaha yang mendorong pertumbuhan dan ekonomi daerah. Namun demikian, dalam membangun kegiatan usaha perlu mempertimbangkan pengkajian yang mendalam terhadap kelayakan atas usaha yang akan direncanakan. Menurut Ref. [6] analisa kelayakan yaitu suatu penelitian yang mendalam terhadap suatu ide usaha tentang layak atau tidaknya ide tersebut untuk dilaksanakan.

Kajian terhadap rencana investasi usaha susu kedelai sebagai home made selanjutnya perlu dikaji melalui studi kelayakan yang meninjau berbagai aspek yang memiliki relevansi yang kuat terhadap perencanaan usaha tersebut. Menurut Ref. [7] home industry yaitu suatu unit usaha atau perusahaan dalam skala kecil yang bergerak dalam bidang industri tertentu. Home berarti rumah, sedangkan industry dapat diartikan sebagai kerajinan, usaha produk barang, ataupun perusahaan. Secara singkat, home industry adalah rumah usaha produk barang atau juga perusahaan kecil.

Susu mengandung sebagian besar zat-zat makanan seperti protein, karbohidrat, mineral, dan vitamin. Kandungan zat-zat tersebut sangat dibutuhkan oleh tubuh. Kandungan gizi susu kedelai hampir mendekati susu hewani. Apabila tidak dapat memenuhi sumber protein yang diperoleh dari daging, maka kebutuhan protein sebesar 55 gram per hari dapat dipenuhi melalui alternatif bahan makanan yang berasal dari kandungan kedelai sebesar 157,14 gram. Oleh karena itu, susu nabati merupakan alternatif pengganti susu sapi [8]. Usaha pengolahan kedelai menjadi susu kedelai dipilih karena dapat memberikan prospek yang bagus dan peluang yang besar dalam mendapatkan income dalam jangka panjang, mengingat permintaannya yang terus meningkat dari waktu ke waktu. Keunggulan usaha home made ini yaitu tidak memakai bahan pengawet atau formalin, kandungan gizi yang baik bagi manusia, serta relatif mudah dalam pembuatannya. Usaha ini hanya menggunakan teknologi dan peralatan yang sederhana dan tidak memerlukan teknologi dan peralatan yang canggih dan mahal. Disamping itu, jenis usaha home made ini tidak mebutuhkan keterampilan khusus.

Susu kedelai yang telah diproduksi akan dipasarkan dan dikemas dalam kemasan plastik dengan ukuran 250 gram. Pada bagian kemasan produk ini diberi label susu kedelai untuk memperintah tampilan. Target konsumen produk susu kedelai ini adalah kelompok menengah ke bawah yaitu masyarakat secara umum, pelajar dan mahasiswa, dan konsumen lainnya. Metode penjualannya yaitu melalui order ke warung-warung, kedai kopi, kios, mini market, dan lainnya yang ada di Kota Banda Aceh. Harga jual dari produk susu kedelai tersebut adalah Rp.3.000,- untuk ukuran plastik seperempat kilogram. Pendekatan penjualan melalui promosi dengan menempel spanduk dan brosur-brosur ditempat strategis seperti warung kopi, kios, kampus dimana orang pada umumnya sering berkumpul, termasuk di lampu merah, halte, dan tempat-tempat lainnya.

Peluang pasar untuk produk yang berbahan dasar kedelai ini sangat menjanjikan, karena kecendrungan masyarakat kita yang umumnya konsumtif. Selain itu daya beli konsumen terhadap produk ini cukup tinggi karena harganya yang sangat terjangkau [9]. Diharapkan produk olahan dari kedelai ini dapat menguasai pasaran dan mampu menciptakan lapangan kerja baru bagi masyarakat sekitar tempat pengolahan susu kedelai tersebut.

\section{TINJAUAN KEPUSTAKAAN}

\section{Analisis Kelayakan}

Kelayakan dapat diartikan bahwa usaha yang akan dijalankan akan memberikan keuntungan finansial dan nonfinansial sesuai dengan tujuan yang mereka inginkan (Jakfar \& Kasmir, 2012). Penelitian studi kelayakan dan hasilnya digunakan untuk mengambil keputusan apakah suatu bisnis dapat dikerjakan atau tidak. Oleh karenya dibutuhkan dasar penelitian studi kelayakan bisnis, yaitu aspek pasar, aspek teknis, aspek manajemen sumber daya manusia, aspek legal dan lingkungan, serta aspek finansial.

\section{Aspek Pasar}

Pasar dan pemasaran memiliki saling ketergantungan satu dengan lainnya dan saling mempengaruhi. Dengan kata lain, setiap kegiatan pasar selalu diikuti oleh pemasaran dan setiap kegiatan pemasaran adalah untuk mencari atau mencipatakan pasar (Jakfar \& Kasmir, 2012). Tiga faktor utama yang menunjang terjadinya pasar, yaitu keinginan dari orang, daya beli, serta tingkah laku dalam pembeliannya (Umar, 2001). 


\section{Aspek Teknis}

Analisis dari aspek operasi adalah untuk menilai kesiapan perusahaan dalam menjalankan usahanya dengan aspek lokasi, luas produksi, dan layout serta kesiagaan mesin-mesin yang akan digunakan (Jakfar \& Kasmir, 2012). Disamping itu, terdapat aspek teknis dan teknologi ini, diantaranya adalah perancangan produk, perencanaan kapasitas, perencanaan proses dan fasilitas, serta perencanaan lokasi (Umar, 2001).

\section{Aspek Sumber Daya Manusia}

Agar proses kegiatan proyek khususnya terkait manajemen dapat bekerja dengan baik, maka organisasi sebagai sarananya perlu dirancang. Hasil akhir dari perancangan organisasi ini yang disebut dengan struktur organisasi (Siregar, 1991). Beberapa aspek manajemen sumber daya manusia, yaitu struktur organisasi, perencanaan kebutuhan tenaga kerja, dan program pelatihan.

\section{Aspek Finansial}

Aspek finansial adalah untuk menentukan rencana investasi melalui perhitungan biaya dan manfaat yang diharapkan dengan membandingkan pengeluaran dan pendapatan, seperti ketersediaan dana, biaya modal, kemampuan usaha untuk mengembalikan biaya dalam jangka waktu yang telah ditentukan dan menilai apakah usaha akan dapat dikembangkan terus (Umar, 2001).

\section{Analisis Sensitivitas}

Dalam studi kelayakan usaha perlu juga untuk dilakukan analisis sensitivitas investasi. Analisis sensitivitas dari rencana investasi terkait parameter yang akan memperlihatkan aspek-aspek yang penting dari suatu permasalahan investasi. Dari analisis sensitivitas dapat diketahui bahwa keputusan tidak sensitif terhadap perubahan estimasi nilai akhir, tetapi pada saat yang sama keputusan tersebut sensitif terhadap perubahan estimasi biaya tahunan

\section{METODE PENELITIAN}

\section{Waktu dan Tempat Penelitian}

Penelitian ini dilaksanakan di Banda Aceh dari bulan Januari sampai bulan Maret 2018. Pemilihan lokasi penelitian dilakukan secara langsung (purposive) karena lokasi merupakan salah satu tempat dimana susu kedelai olahan home made diproduksi untuk dijual.

\section{Prosedur Kerja \\ Pengolahan Susu Kedelai}

Proses pengolahan susu kedelai dimulai dengan melakukan penyortiran untuk memilih biji yang berkualitas baik. Biji kedelai dicuci bersih untuk menghilangkan kotoran yang melekat pada biji. Lalu direndam di dalam air untuk mempercepat proses pelepasan kulit ari agar memudahkan proses penggilingan. Penggilingan menggunakan air dengan perbandingan 1:6 (b/v), perbandingan ini dapat menghasilkan kekentalan sama seperti susu sapi, sehingga diperoleh protein yang tinggi. Kemudian dilakukan penyaringan untuk memperoleh sari kedelai dan filtrat yang diperoleh menjadi susu kedelai. Tahap terakhir yaitu pemanasan untuk membunuh semua organisme patogen dan sebagian mikroorganisme sehingga diperoleh cita rasa dan komposisi susu yang sesuai [10].

\section{Analisa Kelayakan Usaha}

Analisa kelayakan adalah suatu kegiatan yang mempelajari secara mendalam tentang suatu usaha atau bisnis yang akan dijalankan, dalam rangka menentukan dan menganalisis layak atau tidak layak usaha tersebut untuk dibangun dan pada saat dioperasionalkan secara rutin dalam rangka pencapaian keuntungan yang maksimal untuk waktu yang tidak ditentukan [11] [12].

\section{Analisis Data}

Break Event Point (BEP)

BEP Unit $=($ Biaya tetap $) /($ Harga per unit-Biaya variabel per unit $)$

BEP Rupiah $=$ (Biaya tetap) $/($ kontribusi margin perunit/Harga Perunit)

Ket:

BEP Unit/rupiah $\quad$ : BEP dalam unit $(\mathrm{Q})$ dan BEP dalam rupiah $(\mathrm{P})$ 
Biaya tetap

Biaya Variabel

Harga perunit

Biaya variabel perunit

Margin kontribusi perunit
: biaya yang jumlahnya tetap walaupun usaha tersebut tidak sedang berproduksi

biaya yang jumlahnya meningkat sejalan peningkatan jumlah produksi seperti bahan baku, bahan baku pembantu, listrik, bahan bakar dan lain-lain.

: harga jual barang atau jasa perunit yang dihasilkan.

: total biaya variabel perunit (TVC/Q)

: harga jual perunit-biaya variabel perunit (selisih).

\section{Total Cost (TC)}

Rumus yang digunakan untuk menentukan Total Cost (TC) yaitu:

Ket:

$$
\mathrm{TC}=\mathrm{FC}+\mathrm{VQ}
$$

TC : total cost (biaya total)

FC : fixed cost (biaya tetap total)

VQ : biaya variabel total

$\mathrm{V} \quad$ : biaya variabel per unit

Q : quantity atau jumlah produk yang dihasilkan

\section{Total Revenue Analysis (TRA)}

Rumus yang digunakan untuk menentukan Total Revenue Analysis (TRA) yaitu:

$$
T R=P \cdot Q
$$

Ket:

TR : Total revenue atau penerimaan total

$P \quad$ : Price atau harga produk per unit

Q : jumlah produk yang dijuall.

\section{HASIL PENELITIAN DAN PEMBAHASAN}

\section{Analisis Aspek Pesaing}

\section{Produk pesaing (product)}

Susu kedelai yang telah diproduksi akan dipasarkan dan dikemas dalam plastik ukuran 250 gram (seperempat kilogram). Pada plastik diberi label sablon susu kedelai "higienis". Disamping itu, terdapat produk susu kedelai pesaing seperti merek Zoya, Bear brand dan merek susu kemasan lainnya yang dijual di mini market, toko-toko, dan kios. Keberadaan susu tersebut memang memberikan dampak persaingan. Namun demikian, produk tersebut menjadi konsumsi rumah tangga dan masyarakat umumnya, karena produk tersebut sudah berskala nasional. Produk susu kedelai home made ini masih dipilih oleh konsumen utamanya yaitu siswa, mahasiswa, maupun masyarakat lokal yang sering duduk di warung-warung dan warung kopi di sekitar Kota Banda Aceh.

Berdasarkan beberapa wawancara dengan masyarakat yang membeli produk susu kedelai, alasan mereka memilih produk tersebut adalah karena konsumen lebih menyukai produk lokal yang produksinya masih fresh dan relatif. Disamping itu, harganya yang sangat terjangkau dan juga rasa, serta kualitas yang tidak jauh berbeda jika dibandingkan produk pesaingnya.

\section{Lokasi/distribusi (place)}

Usaha susu kedelai ini berlokasi di daerah Darussalam Banda Aceh. Sasaran utama pemasaran poduk susu kedelai adalah para mahasiswa di kampus, baik yang berada di Universitas Syiah Kuala Darusalam, maupun kampus atau sekolah lainnya, serta masyarakat umum yang sering duduk di warung kopi. Penjualan di lingkungan kampus dilakukan dengan cara menitipkan produk susu kedelai tersebut di kantin kampus, Kopma, dan termasuk di toko atau warung-warung di sekitarnya. Demikian juga di tempat lainnya seperti mini market dan warung kopi lainnya di sekitar Banda Aceh.

\section{Harga (price)}

Penentuan harga jual dilakukan dengan cara menghitung biaya produksi ditambah biaya lain-lain dan tentunya dengan pertimbangan bahwa harga harus di bawah harga pesaing, agar dapat menarik konsumen lainnya. Sedangkan harga jual dari produk susu kedelai ini yaitu Rp. 3.000,- dengan ukuran plastik seperempat kilogram. Sedangkan, harga pesaing seperti susu zoya dan merek lainya dibanderol dengan harga lebih dari Rp. $7.000 \mathrm{per} \mathrm{botol/kemasan.}$ 


\section{Promosi (promotion)}

Promosi dilakukan melalui cara mengenalkan produk susu kedelai tersebut kepada konsumen melalui brosur-brosur, menempel pamflet di pinggir jalan atau tempat-tempat strategis lainnya, seperti kios dan warungwarung di sekitaran Kota Banda Aceh. Disamping itu, dilakukan promosi dengan memanfaatkan buletin yang terbit di kampus dan media internet sebagai sarana e-business. Untuk promosi melalui internet akan dipromosikan lewat facebook dan situs-situs e-business lainnya seperti "berniaga.com" dan lainnya.

\section{Analisis Peluang Pasar}

Peluang pasar untuk produk yang berbahan dasar kedelai ini masih menjanjikan, karena melihat ekspektasi masyarakat untuk dapat mengkonsumsi minuman sehat dan bergizi dari produk lokal. Selain itu daya beli komsumen terhadap produk ini sangat tinggi, karena harganya jauh lebih murah dan terjangkau. Agar dapat menembus pasar yang lebih luas dan pemasaran yang dilakukan optimal, maka perlu pertimbangan penentuan strategi yang akan diambil untuk membangun usaha. Disamping itu, agar mendapatkan respon positif dari konsumen, maka perlu dilakukan promosi di lingkungan internal dan eksternal yang ada di pasar domestik sebagai pendukung analisa kelayakan usaha yang dilakukan.

\section{Analisis Aspek Finansial}

Agar dapat mengetahui aspek pembiayaan usaha pembuatan dan pengolahan susu kedelai, maka terlebih dahulu perlu dilakukan perincian terhadap biaya-biaya yang di butuhkan. Biaya yang dihitung mencakup biaya tetap dan biaya variabel. Rincian biaya tetap (fixed cost) untuk membangun usaha susu kedelai olahan home made dapat dilihat pada Tabel 1, sedangkan biaya variabel dalam mengambangkan usaha susu kedelai dapat dilihat pada Tabel 2

Tabel 1. Biaya tetap pengembangan usaha susu kedelai

\begin{tabular}{lcccc} 
Uraian & $\begin{array}{c}\text { Jumlah } \\
\text { (unit) }\end{array}$ & $\begin{array}{c}\text { Harga } \\
(\mathrm{Rp})\end{array}$ & $\begin{array}{c}\text { Masa pakai } \\
\text { (tahun) }\end{array}$ & $\begin{array}{c}\text { Total harga } \\
(\mathrm{Rp})\end{array}$ \\
\hline Sewa tempat & 1 & 15.000 .000 & 1 tahun & 15.000 .000 \\
Diesel giling & 1 & 1.835 .000 & 10 tahun & 1.835 .000 \\
Kain 1 meter & 2 & 5.000 & 1 tahun & 10.000 \\
Gunting & 5 & 7.000 & 2 tahun & 35.000 \\
Bak & 6 & 25.000 & 2 tahun & 150.000 \\
Keranjang & 4 & 30.000 & 2 tahun & 120.000 \\
Kompor & 4 & 275.000 & 6 tahun & 1.100 .000 \\
Panci & 4 & 600.000 & 6 tahun & 2.400 .000 \\
Gaji karyawan & 7 & 1.000 .000 & 1 bulan & 7.000 .000 \\
\hline \multicolumn{7}{c}{ Total } \\
\hline
\end{tabular}

Sumber : Hasil olahan data primer, 2020

Tabel 2. Biaya tetap pengembangan usaha susu kedelai

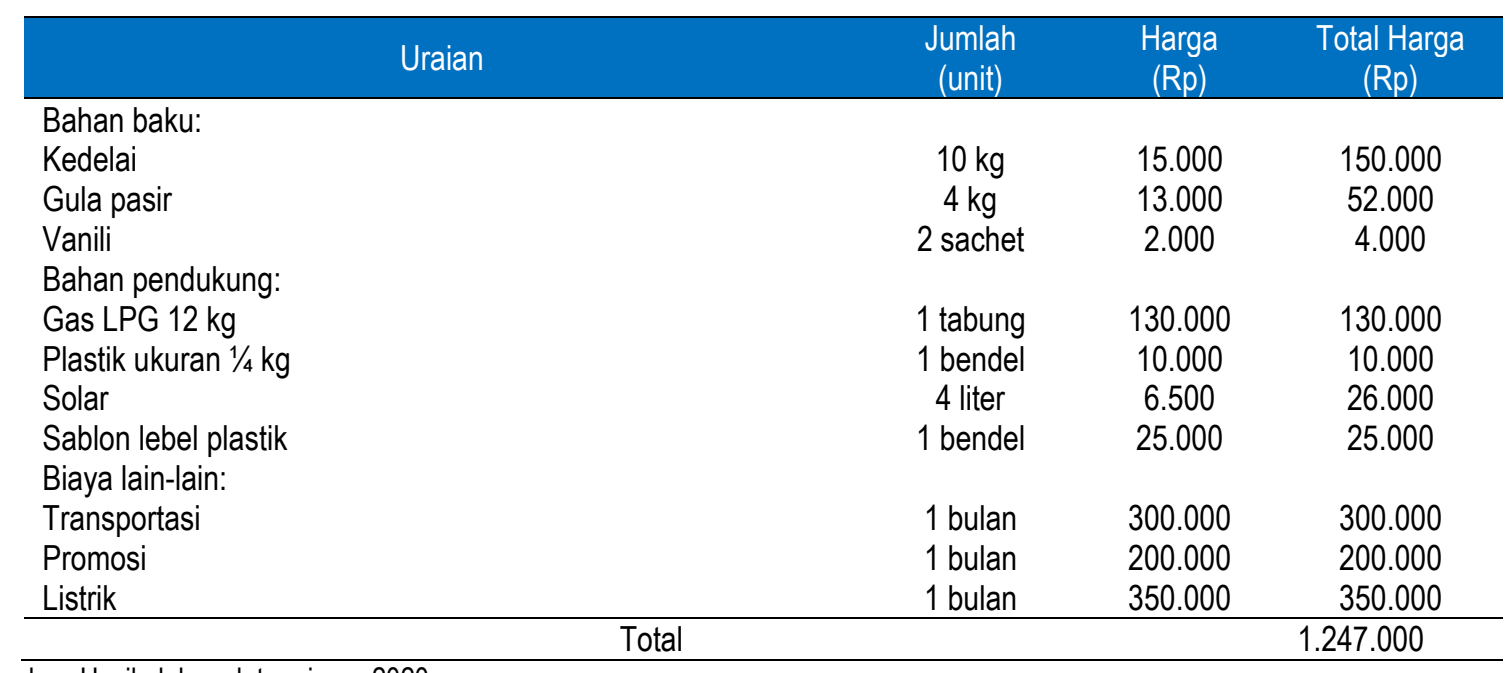

Sumber: Hasil olahan data primer, 2020. 
Tabel 3. Jumlah Biaya Usaha

\begin{tabular}{cc}
\hline Jenis biaya & Total biaya \\
\hline Biaya tetap & 27.650 .000 \\
Biaya variabel & 1.247 .000 \\
\cline { 2 - 3 } Sumber: Hasil olahan data primer, 2020 & 28.897 .000 \\
\hline
\end{tabular}

Tabel 3. menunjukkan biaya tetap yang dikeluarkan oleh pengusaha susu kedelai yaitu sebesar Rp. 27.650.000,- dan biaya variabel sebesar Rp. 1.247.000,-. Jadi biaya total yang dikeluarkan untuk memproduksi susu kedelai olahan home made di Kp. Ateuk Pahlawan Kecamatan Baiturahman Kota Banda Aceh adalah sebesar Rp. 7.645.067,-. Menurut Ref. [13] suatu usaha dapat dikatakan sukses jika nilai hasil proses produksi yang diperoleh minimal cukup untuk membayar semua sarana produksi, membayar biaya modal, dan membayar biaya tenaga kerja atau biaya tak terduga lainnya selama proses produksi.

Pengolahan Data Dengan Menggunakan Break Event Point, Total Cost, dan Total Revenue Analysis

Dari data biaya tetap pada Tabel 1 dan biaya variabel pada Tabel 2, maka dapat dihitung BEP (Break evet point) dalam unit dan rupiah sebagai berikut:

Dengan persamaan $Y=c x-b x-a, B E P$ tercapai bila $Y=0$, maka dalam hal ini adalah

$c=$ Rp. 3.000 (harga satuan susu kedelai olahan)

$x=500$ bungkus (jumlah susu kedelai yang dipasarkan)

$a=$ Rp. 27.650 .000 (biaya tetap)

$b x=$ Rp. 1.247 .000 (biaya variable)

$\mathrm{b}=\mathrm{bx} / \mathrm{x}$

maka:

$b=1.247 .000 /(500)=2.494$

selanjutnya,

$X$ BEP u $=a /((c-b))$

$X$ BEP u $=27.650 .000 /((3.000-2.494))$

$=27.650 .000 / 506$

$=54.645$ bungkus

Dalam rupiah dapat dihitung sebagai berikut:

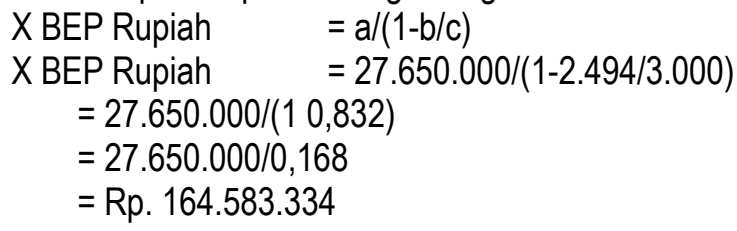

Total cost dan total revenue analysis untuk susu kedelai:

$\mathrm{TC}=\mathrm{FC}+\mathrm{VQ}$

$\mathrm{TC}=27.650 .000+1.247 .000$

$\mathrm{TC}=28.897 .000$

$T R=P . Q$

$\mathrm{TR}=(3.000) \times(500)$

$\mathrm{TR}=1.500 .000$

Analisis Break Even Point merupakan suatu analisis yang bertujuan untuk menemukan titik dalam kurva biaya pendapatan yang menunjukkan biaya sama dengan pendapatan selanjutnya. Dalam melakukan nalisis pulang pokok diperlukan estimasi mengenai biaya tetap, biaya variabel, dan pendapatan. Biaya tetap (fixed cost) adalah biaya yang dikeluarkan dengan nominal yang tetap, tidak tergantung dari volume penjualan, sekalipun perusahaan tidak melakukan penjualan. Biaya variabel (variabel cost) merupakan biaya yang besarnya bervariasi sesuai dengan jumlah unit yang diproduksi/dijual. Sedangkan pendapatan merupakan elemen lain dalam analisis pulang pokok yang nominalnya bertambah sesuai dengna pertambahan volume penjualan [14]. Sedangkan Ref. [15] menyatakan bahwa Break Even Point adalah tiitk dimana total pendapatan sama dengan total biaya, titik 
dimana laba sama dengan nol. Oleh karena itu, dibutuhkan usaha dalam meningkatkan laba untuk memperoleh laba yang maksimum dengan melihat volume penjualannya. Dari hasil perhitungan di atas, maka dapat dibuat grafik perhitungan biaya usaha susu kedelai seperti yang terlihat pada Gambar 1.

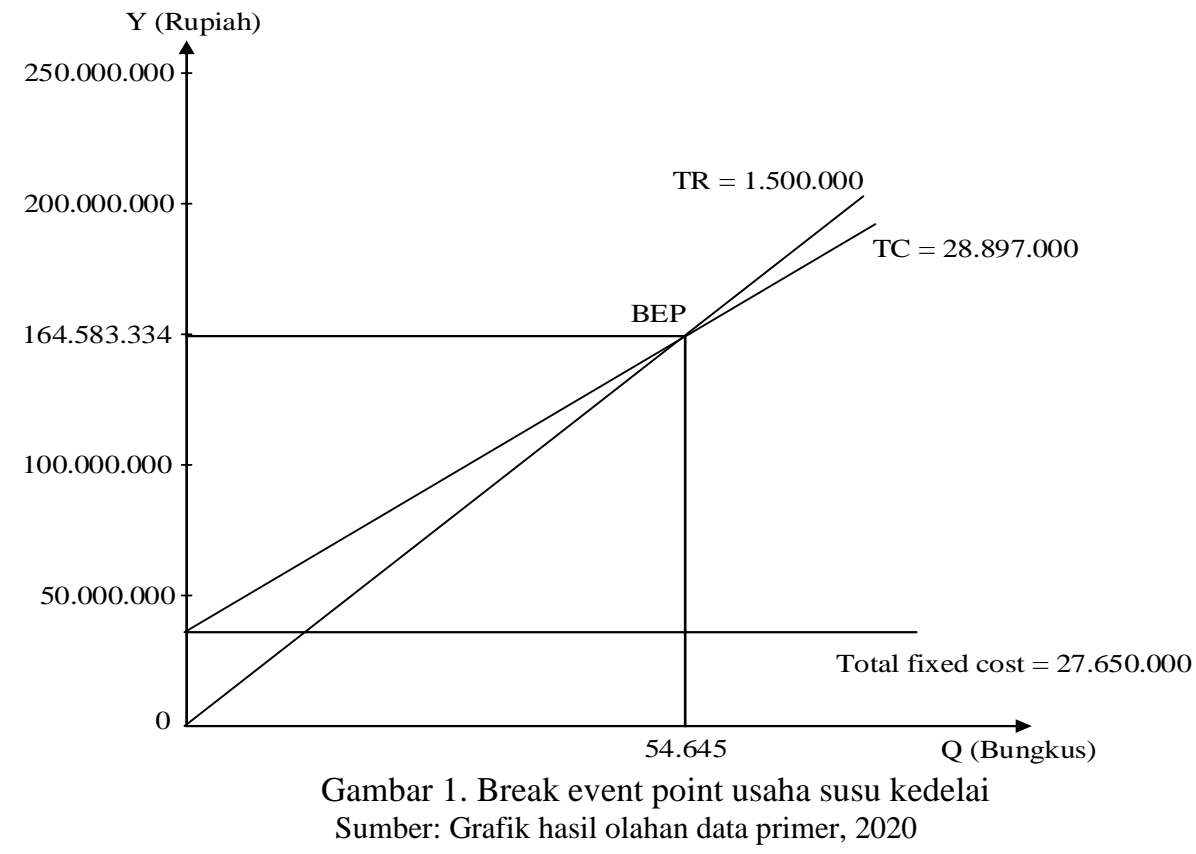

Berdasarkan Gambar 1. menunjukkan bahwa produksi susu kedelai dengan bahan baku kacang kedelai dapat dilaksanakan karena mampu memberi keuntungan yang layak (feasible). Menurut Ref. [16] studi kelayakan adalah sebuah studi untuk mengkaji secara komprehensif dan mendalam terhadap kelayakan suatu usaha. Layak atau tidak layak dijalankannya suatu usaha tergantung pada hasil pembandingan semua faktor ekonomi yang akan dialokasikan ke dalam usaha tersebut dengan hasil pengembaliannya akan diperoleh dalam jangka waktu tertentu. Ref. [17] juga melaporkan bahwa studi kelayakan sering disebut dengan feasibility study yang merupakan bahan pertimbangan dalam mengambil suatu keputusan, apakah menerima atau menolak dari suatu gagasan usaha yang direncanakan. Pengertian layak dalam penilaian ini adalah kemungkinan dari gagasan usaha yang akan dilaksanakan memberikan benefit (manfaat), baik itu financial benefit maupun social benefit.

\section{KESIMPULAN}

Berdasarkan hasil analisis kelayakan usaha industri susu kedelai maka dapat disimpulkan bahwa dari penghitungan BEP dihasilkan pada bulan ke-4, dimana terjual sebesar 54.645 bungkus dan BEP Rupiah yaitu sebesar Rp.164.583.334. Dimana total cost sebesar Rp.28.897.000,- dan total revenue sebesar Rp.1.500.000.Setelah dilakukan analisis terhadap hasil perhitungan, maka usaha ini layak untuk di kembangkan.

\section{REFERENSI}

[1] http://duniaplant.blogspot.com/2015/06/klasifikasi-dan-morfologi-tanaman-kedelai.html diakses pada Tanggal 06 Maret 2020

[2] Rukmana, R. dan Y. Yuniarsih, Kedelai Budidaya dan Pascapanen, Kanisius, Yogyakarta, 1996.

[3] Wahyudin, A, F.Y. Wicaksono, A.W. Irwan, Ruminta, R. Fitriani, "Respons tanaman kedelai (Glycine max) varietas Wilis akibat pemberian berbagai dosis pupuk N, P, K, dan pupuk guano pada tanah Inceptisol Jatinangor," Jurnal Kultivasi, Vol. 16(2) Agustus, 2017.

[4] L. Muhuria, K. Ning Tyas, N. Khumaida, Trikoesoemaningtyas, dan D. Sopandie, "Adaptasi Tanaman Kedelai Terhadap Intensitas Cahaya Rendah : Karakter Daun untuk Efisiensi Penangkapan Cahaya," Bul. Agron, (34) (3) $133-140,2006$

[5] M. Astawan dan A. E. Febrinda, "Isoflavon Kedelai Sebagai Antikanker," Pangan 42, No. 55/XVIII/JuliSeptember, 2009. 
[6] A. Subagyo, Studi Kelayakan Teori dan Aplikasi, Jakarta: PT. Gramedia, 2008.

[7] G. Rosalita Armelia dan A. Damayantie, "Peran PTPN VII dalam Pemberdayaan Home Industri Keripik Pisang," Jurnal Sociologie, Vol 1: 339, 2014.

[8] S. Santoso, Kesehatan dan Gizi, Jakarta : Rineka Cipta, 2009.

[9] Tjiptono dan Fandi, Strategi Pemasaran, Andi Offset, Edisi Kedua, Cetakan Pertama, Yogyakarta, 1997.

[10] M. Adnan, Kimia dan Teknologi Pengolahan Air Susu, Andi Offset, Yogyakarta, 1984.

[11] Kasmir dan Jakfar, Studi Kelayakan Bisnis, Kencana, Jakarta, 2007.

[12] U. Husein, Studi Kelayakan Bisnis, Edisi 3, Gramedia Pustaka Utama, Jakarta, 2005.

[13] Salahudin dan L. Saleh, "ANALISIS KELAYAKAN USAHA PENGOLAHAN SUSU BUBUK KEDELAI (Studi Kasus UD. Konawe Raya di Kabupaten Konawe)," SEMNAS PERTANIAN, 2018.

[14] Herjanto, Eddy, Manajemen Operasi, Grasindo, Jakarta, 2007.

[15] D.R. Hansen dan M.M. Mowen, Akuntansi Manajemen I, (Terjemahan Edisi Ketujuh), Salemba Empat, Jakarta, 2006.

[16] Johan, S, Studi Kelayakan Pengembangan Bisnis, Graha IImu, Yogyakarta, 2011.

[17] Ibrahim, Y, Studi Kelayakan Bisnis, Rineka Cipta, Jakarta, 2009.

[18] Jakfar \& Kasmir., 2012, Studi Kelayakan Bisnis, Edisi Revisi, Penerbit Kencana Prenada Media Grup, Jakarta.

[19] Umar, Husein. 2001. Studi Kelayakan Bisnis. Gramedia Pustaka Utama. Jakarta.

[20] Siregar, Ali Basyah., 1991, Analisis Kelayakan Pabrik, Institut Teknologi Bandung, Bandung. 